\title{
新しい分析法による茶の品質に係わる成分の研究
}

\author{
農林水産省野菜・茶業試験場 \\ 永田忠 博†
}

\section{New Analytical Methods for Studying Tea Quality Components}

茶葉の分子レベルの特徵は，カフェイン・カテキ ン類・テテニンなど，一般の植物に見られない2 次 代謝物が多いことであり，これらは茶の品質・効能 に密接に係わる成分である。さらにテルペン・サポ ニンなどの成分も茶には重要な因子である。

原子レベルの茶葉の特徽は, アルミニウム・フッ 素が多いことである。両元素は特に古葉に多い。フ 素は茶の虫電予防効果と関俰がある。また「茶は 土を選ばず」と言われ，酸性土壤の有害因子である アルミニウムを蓄積しても障害を生じない。これは 茶樹体内で，アルミニウムを解萻する生化学的機構 があるためと考完られる。

最近進歩が著しい分析機器を利用し，これら成分 や元素の存在形態を調査すれば，茶の生産・品質向 上に有用な知見が得られる。そこで新しく導入され た分析機器を活用して，以下の研究を行った。

まずカフェイン・カテキン類・テアニンなど特有 の2次代謝物についてチャの近縁種・雑種に扣ける 分布を調查し、ッバキ属のチャ節植物と他の植物の 成分の違い,チャ雑種の成分の特櫬を明らかにした。 また非破壊分析により，葉内アルミニウムの主たる 存在形態が、カテキンとの錯体であることを示した。 同時に茶輪斑病菌の産生する病原毒素を構造解析 し，近縁種の有する茶病原菌に対する抗菌性物質に ついてわ調查した。

\section{1 茶の 2 次代謝物の近緑種・雑種の分布}

茶の重要な構成成分であるカフェイン・カデキン 類・アミノ酸について,ッバキ属各種とチャの種間 雑種に拈ける新葉中含量を調査した。

その結果，チャ節植物はエステル型カテキン，カ
フェインもしくはテオブロミン，テアニンを高濃度 に含有する。これに対し、ッバキやサザンカなどの チャ節以外のッバキ属植物はこれらを含有しない か，例外的に検出したとしても，ごく微量であるこ とがわかった。したがって，これらの成分はチャ節 植物の特有成分といえる。これをまとめると，表 1 のようになるが，抗腫瘍作用など注目すべき活性を 有する，茶に最も多い成分のエピガロカテキンガ レート（エステル型カテキンの1種）がチャ節植物 にのみ検出されたことは注目される。またッバキ， サザンカ中のテアニンは, 実生幼植物のみ高濃度に 存在することが，その後の津志田らの研究に上りわ かっている。

またチャ節植物に，カフェイン生合成経路がチャ と異なる種があった。チャ節のイラワジェンシスは， すでにカフェインを含まない種として知られてい る。をこでカフェインとその前駆体テオブロミンを 同時分析し，図1に示す上らな結果を得た。図1か らわかるよらに, イラワジェンシスは痕跡量のカフ ェインと相当量のテォブロミンを含有する。これは， カフェイン生合成の最終段階のメチル化が行われず テオブロミンを蓄積したためと考えられた。残念な がら, 本研究で入手できたチャ節植物は 3 種であり， 茶の起源地にある未入手植物の今後の分析が望まれ る。

さらに，チャとサザンカ，チャとッバキなどの種 間雑種の新葉成分を分析すると，片親のサザンカ， ッバキから検出されないエステル型カテキン，カフ ェイン,テアニンが検出された。しかし，チャに比 べてその濃度は一般に低い。同様炕ザンカの特有 成分である苦味物質サザンキンも，サザンカとチャ 
表 1. 茶近緑種に批ける茶葉成分の分布

\begin{tabular}{|c|c|c|c|c|c|}
\hline 植物 & \multicolumn{2}{|c|}{$\begin{array}{c}\text { メチルキサンチン } \\
\text { テオプロ } \\
\text { テン } \rightarrow \text { カフェイン }\end{array}$} & \multicolumn{2}{|c|}{$\begin{array}{c}\text { カテキン } \\
\text { 遊離型 } \rightarrow \text { エステル型 }\end{array}$} & テアニン \\
\hline チャ節 & + &,+- & + & + & + \\
\hline チャ節以外のッバキ属 & - & - &,+-- & - & \pm \\
\hline
\end{tabular}

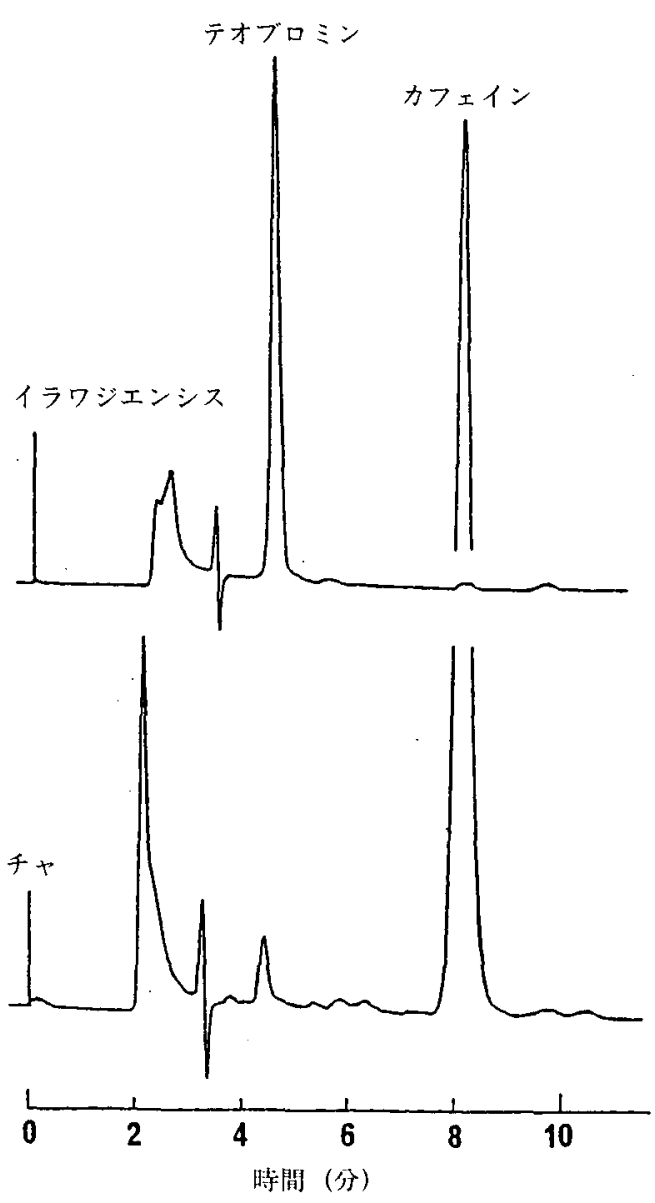

图1.チャとイラワジェンシスのカフェイン， テオブロミンの同時分析

の雑種に含まれている。雑種とその雨親の化学成分 についてまとめると, 表 2 のらになる。この結果 から，片親にしかない成分の生合成能力が雑種に遺 伝したことがわかる。㷌属不明種のワビスケは，チ けとツバキの雑種の可能性も報告されていたが，成 分分析の結果, 茶の特有成分がなく, チャ雑種の可 能性は否定された。

以上の知見は，チャ節植物の遺伝資源としての重 要性を示すとともに，今後の種間雑種を利用した育 種に有用と考えられる。
表 2 . 雑種とその両親の化学成分

\begin{tabular}{|c|c|c|c|}
\hline 成 分 & チャ & ッバキ/ササンカ & 雑種 \\
\hline カ $7 x 1$ Y & + & - & + \\
\hline エステル型カテキン & $t$ & - & + \\
\hline$P=V$ & + & - & + \\
\hline サザンキン & - &,-+ &,-+ \\
\hline
\end{tabular}

\section{2 チャのアルミニウムとフッ素}

チャの古葉は，アルミニウム (Al)とフッ素 $(\mathrm{F})$ の両元素が高濃度という特徽があるが,これはチャ と同族のツバキやサザンカも同様である。両元素と も核磁気を有するのでNMR（核磁気共鳴法）の対 象となる。

茶樹の $\mathrm{Al}$ 代謝については樹体内成分之結合し解 毒されると考光られており，その成分として，これ まで $\mathrm{F}$, 有機酸, カテキンを含むポリフェノールな どが挙げられてきた。そこで，茶葉内 $\mathrm{Al}$ の蓄積形 態と樹体内 $\mathrm{Al}$ の存在形態を調查し，その耐酸性機 構を解明するためNMRによる直接測定を試みた。 生体組織の Al の直接測定はこれまでに報告はない が，測定条件の改良に上り茶樹体各部の $\mathrm{Al}$ スペク トルが測定可能となった。

この条件で測定した，茶葉と $\mathrm{Al}$ 錯体標準溶液の スペクトルを図 2 に示す。この実験結果より, 茶葉 中 $\mathrm{Al}$ の主たる存在形態は有機酸や $\mathrm{F}$ との錯体でな く， $\mathrm{Al}$ ーカデン錯体であることが示された。 $\mathrm{Al}$ による障害発言は，カテキンにより抑えられている 訳であり, カテキンの生理的重要性の一面が明らか となった。

これに対し根・幹・枝では, 図 3 に示すよらに力 テキン錯体以外の形態がある。この $\mathrm{Al}$ ーカテキン 錯体の高周波数側（右側）の吸収は，アルミニウム の転流形態とも考学られ，今後の研究が期待される。

一方Fについては，通常の茶葉や幹を F-NMR で直接測定しても，樹体内の $\mathrm{F}$ に由来寸る吸収は得 


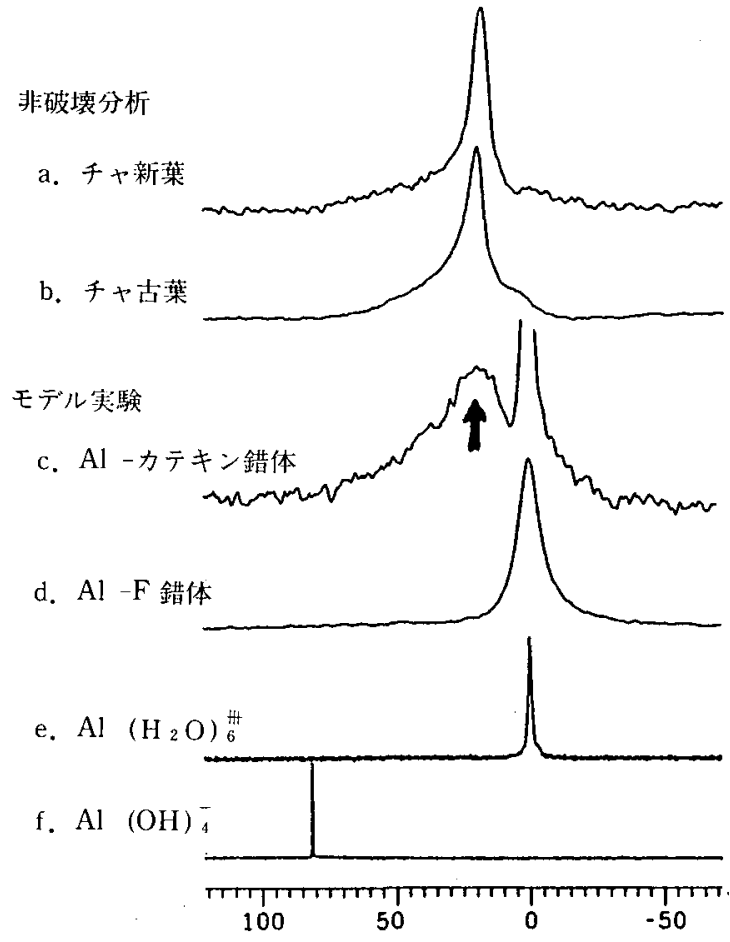

因 2. 茶葉 $\mathrm{Al}$ 錯体標準溶液の ${ }^{27} \mathrm{~A} 1$ の NMR

られない。しかし，切り枝試験で $\mathrm{Al}-\mathrm{F}$ 錯体， Fイオンいずれを吸わせても，枝では吸収液と同じス ペクトルが得られる。しかし葉は, 通常量の数倍程 度に $\mathrm{F}$ 濃度が上昇してわ，F吸収は観測されない。 このことから，Fは転流中に化学的形態に变化がな いが，葉で速やかに蓄積形態に変化すると推察され

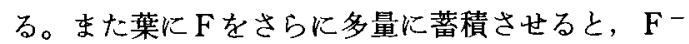
イオンと注注一致する領域にブロードな吸収が観測 された。この領域はまた炭化フッ素の観測領域でも ある。

また茶の浸出夜中のフッ素の形態は虫歯予防など の面からも注目されるが，NMR測定の結果は図 4 に示す通りであり， F-イオンが主であり，F-Al 錯体も認められる場合むあった。 $\mathrm{Al}$ と Fの含量に

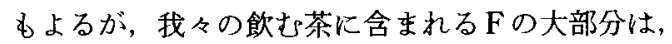
単なるFーイオンと考克られた。

\section{3 茶病害の抗菌性物質}

チャと同属のツバキ，ワビスケの葉の煎汁が，チ 十炭そ病菌・輪斑病に対し異常発芽を誘起する抗菌 活性を示すことが浜屋により発見された。その生理 活性成分 2 種が津志田により単離されたので，両成 分の構造解析を行った。その構造は図 5 に示す通り

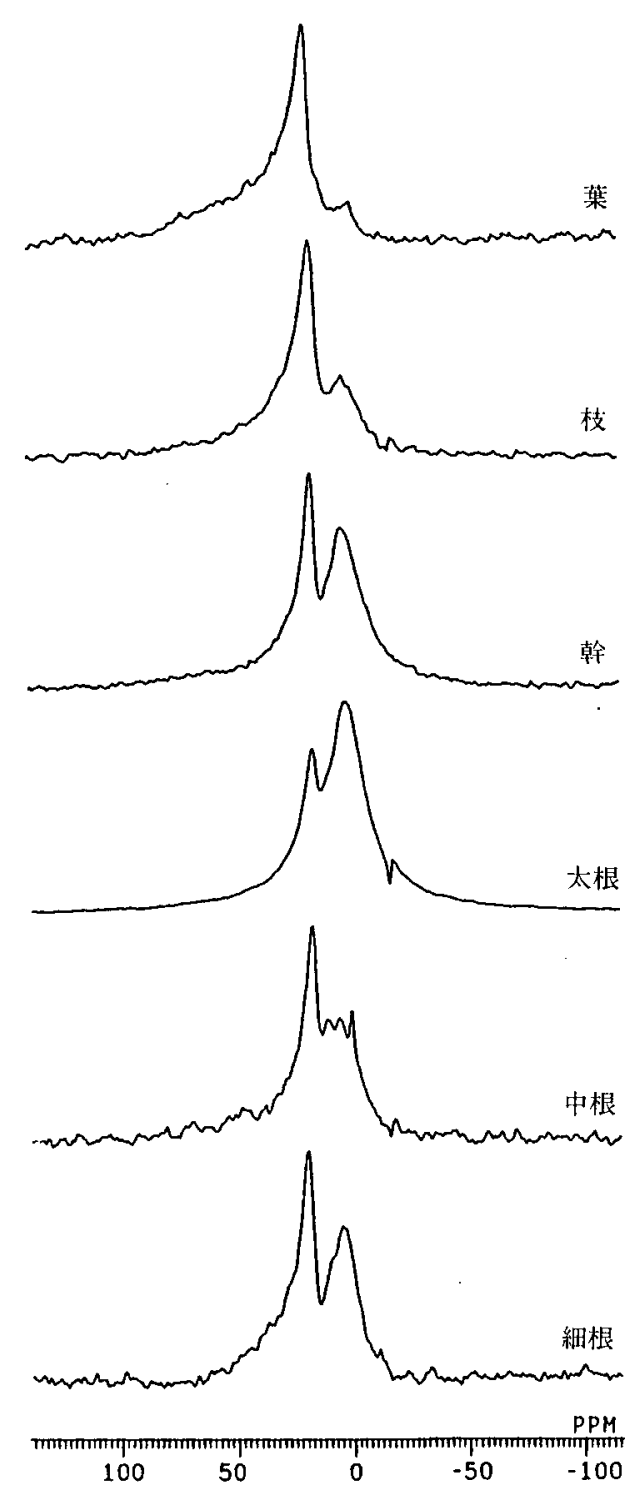

图 3 . 茶樹各部位の ${ }^{27} \mathrm{Al}$ の NMR の例

であり、いずれもトリテルペノイド系サポニンの新 規化合物であった。雨者は，活性の強いるのからカ メリジンI，カメリジンIIと命名した。カメリジン は 1000 以上の大分子であり，トリテルペンと4つ の単糖よりなる。

本研究は三菱化成生命化学研究所との共同研究で

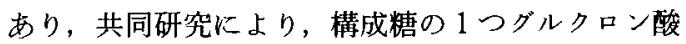
が発芽阻止活性の第一要因と推定された。したがっ て，サポニンにこだわらずグルクロン酸に適当な親 水基, 疎水基を結合させた新規活性物質の利用も考 えられる。

ッバキは病害に強いといわれるが，カメリジンの 

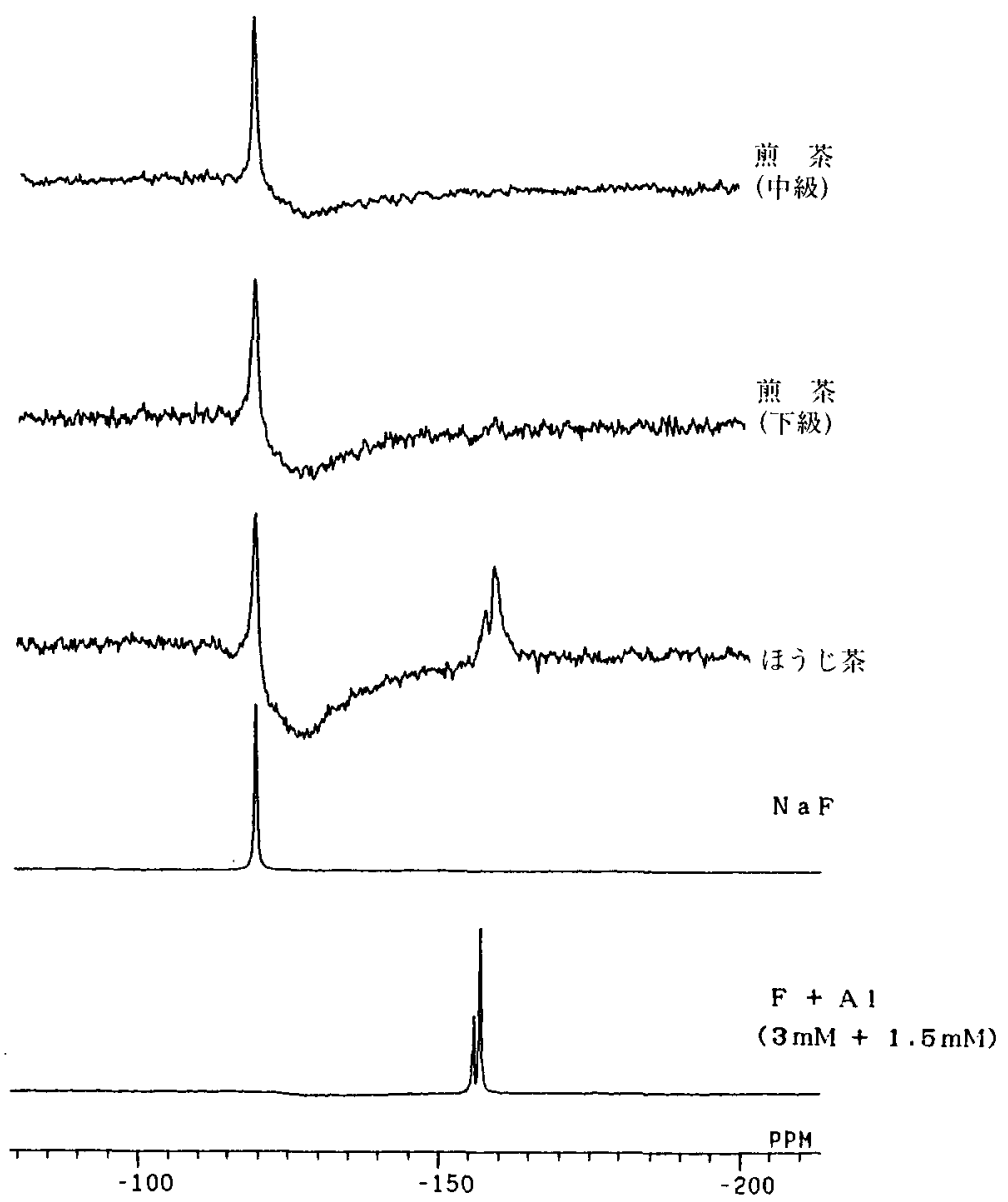

図 4 . 茶侵出液 ${ }^{19} \mathrm{~F}-\mathrm{NMR}$

抗菌活性の強さや，作用を受ける菌の種類の多さか ら,ッバキでは䒺状菌の侵入感染比する抵抗性に， カメリジンが少なからず関与しているものと考兄ら れる。しかし，チャとッバキの種間雑種 9 系統から は，カメリジンの活性は㭘出されず，カィリジンは 存在しないか，存在してもごく锺量と推定される。 トリテルペノイド系サポニンは，これまでにチャや ッバキから多数分離されて招り，茶樹にも未発見の 多様なサポニンが含をれていると考えられる。将来, ツバキ属サポニンの研究が進めば，その知見は耐病 性品種育成や天然物由来の活性物質の利用に役立つ であらう。

\section{4 茶輪斑病の病原毒素}

茶輪斑病は 1970 年代から被害が大きくなり，急 速に全国に扗大した。発病過程の観察から，本病は 病原菌の産生する毒素が, 病斑形成に関与すると推

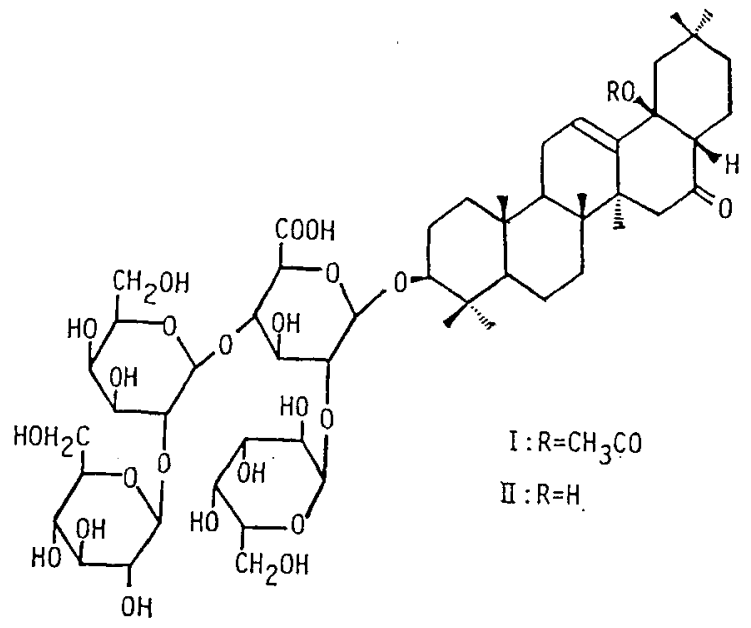
定された。そこで，本菌の培着液中の壊死斑形成能

因 5 .カメリジンの構造式

I : カイリジン I
II : カメリジンII 


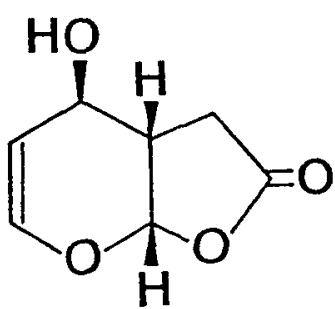

(a)オキシスボロン

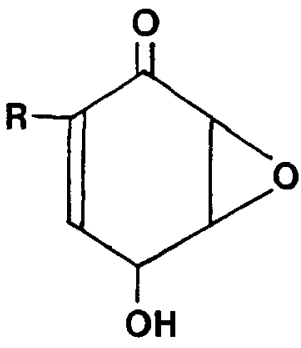

1: $\mathrm{R}=\mathrm{CH}_{2} \mathrm{OH}$

2: $\mathrm{R}=\mathrm{C} \equiv \mathrm{C}-\mathrm{C}=\mathrm{CH}_{2}$ $\mathrm{CH}_{3}$

図 6. Fャ輪斑病菌の素素の化学構造

1 Pestalotia longiseta $り$,

2 Pestalotiopsis theaeより単離

を有する物質を検索し，これらの単離に成功した。 生物検定と精製は安藤により行われ，日本で大きな 問題となっているPestalotia Longiseta からは 2 種, インドなどで被害の報告されているPestalotiopsis theaeからは 1 種の計 3 種の毒素が得られた。機器 分析の結果明らかとなった，3 種の芼素の構造は図 6 の通りである。

Pestalotia longisetaから最初に単離された毒素は， NMR及びMSスペクトルより，Oxysporone と命 名された化合物であることがわかった。この物質は， ナイジェリアの赤痢の民間療法薬中の糸状菌 Fusarium oxysporum の生産する抗生物質として報 告されている。本物質の報告はこれが唯一のもので， 植物毒であることは今回初めて発見されたことにな る。またGC／S I M（選択的イオンモニタリング 法）により, 茶葉の病斑中の Oxysporone の存在も 確認され，本物質が輪斑病の発病に係わることる証 明された。Oxysporone の発見は Fusarium oxysporumからで势るので，野菜の重要な病害を引き起 こす Fusarium oxysporum の病原菌系統に, 本物質 を産生するものがあるのか，注目されるところであ る。

2 番目に Pestalotia longiseta から単離された毒素 は，いずれも新規エポキシ化合物である。その構造 解析は, 天然存在比約 $1 \% の^{13} \mathrm{C}$ 核同志の結合を観 測するINADEQUATEといらNMRの特別な手法 を用いた。

これと同じ環構造を有する Pestalotiopsis theae の 毒素は, 部分構造が異なり, 毒素としての活性はこ ちらの方が強い。この化合物は微小管配向制御物質 としてCurvularia 属系状菌上り単離され, Harvey none といら名称で 89 年秋に報告されている。微小 管配向を制御する細胞分裂停止物質は，細胞分裂の 機構解析, Aging に関する研究, ガンなどの化学治 療, 培盖細胞による物質生産なと広い応用が期待で きる。

植物毒素として単離された上記の 3 種化合物は， いずれも分子量200以下の小分子で，特異な復素環 化合物であることは注目されてよい。今後の生理活 性試験の中から，有効な活性の発見されることを期 待したい。

\section{参考 文 献}

1) Nagata, T. and S. SAKaI : Japan. J. Breed., 34, 459 (1984).

2) Nagata, T. and S. SAKaI : Japan. J. Breed., 35, 1 (1985).

3 ) Nagata, T. and S. Sakai : Phytochem., 24, 2271 (1985).

4 ) 永田忠博 - 酒井㥀介: 茶 技 研, No. 67,1 (1985).

5 ）永田忠博 -小营伸郎：農化講要, 64, 55 (1990).

6 ）永田忠博 - 早津雅仁 - 茶研報, 72 (別冊)， 64 (1990).

7 ）浜屋悦次·津志田藤二郎·永田忠博 - 西野親生 榎 伸康·真部俊一：日植病報，50，628 (1984).

8 ) Nagata, T. T. Tsushida, E. Hamaya, N. Enoki, S. Manabe and C. Nishino : Agric. Biol. Chem. 49, 1181 (1985).

$9)$ Nishino, C., S. Manabe, N. Enoki, T. Nagata, T. Tsushida and E. Hamaya : J. Chem. Soc., 
Chem. Commun., 1986, 720 (1986).

10) Nagata, T. and Y. Ando : Agric. Biol. Chem.
53, 2811 (1989).

11）安藤康雄, 永田忠博: 特許申請中 